\title{
Review \\ Science review: Mechanisms of impaired adrenal function in sepsis and molecular actions of glucocorticoids
}

\author{
Hélène Prigent ${ }^{1}$, Virginie Maxime ${ }^{1}$ and Djillali Annane ${ }^{2}$
}

\begin{abstract}
${ }^{1}$ Senior Resident, Service de Réanimation Médicale, Hôpital Raymond Poincaré (Assistance Publique Hôpitaux de Paris), Faculté de Médecine Paris lle de France Ouest (Université de Versailles Saint-Quentin en Yvelines), Garches, France

${ }^{2}$ Director of the ICU, Service de Réanimation Médicale, Hôpital Raymond Poincaré (Assistance Publique Hôpitaux de Paris), Faculté de Médecine

Paris lle de France Ouest (Université de Versailles Saint-Quentin en Yvelines), Garches, France
\end{abstract}

Corresponding author: Professor Djillali Annane, djillali.annane@rpc.ap-hop-paris.fr

Published online: 25 May 2004

Critical Care 2004, 8:243-252 (DOI 10.1186/cc2878)

This article is online at http://ccforum.com/content/8/4/243

(c) 2004 BioMed Central Ltd

\begin{abstract}
This review describes current knowledge on the mechanisms that underlie glucocorticoid insufficiency in sepsis and the molecular action of glucocorticoids. In patients with severe sepsis, numerous factors predispose to glucocorticoid insufficiency, including drugs, coagulation disorders and inflammatory mediators. These factors may compromise the hypothalamic-pituitary axis (i.e. secondary adrenal insufficiency) or the adrenal glands (i.e. primary adrenal failure), or may impair glucocorticoid access to target cells (i.e. peripheral tissue resistance). Irreversible anatomical damages to the hypothalamus, pituitary, or adrenal glands rarely occur. Conversely, transient functional impairment in hormone synthesis may be a common complication of severe sepsis. Glucocorticoids interact with a specific cytosolic glucocorticoid receptor, which undergoes conformational changes, sheds heat shock proteins and translocates to the nucleus. Glucocorticoids may also interact with membrane binding sites at the surface of the cells. The molecular action of glucocorticoids results in genomic and nongenomic effects. Direct and indirect transcriptional and post-transcriptional effects related to the cytosolic glucocorticoid receptor account for the genomic effects. Nongenomic effects are probably subsequent to cytosolic interaction between the glucocorticoid receptor and proteins, or to interaction between glucocorticoids and specific membrane binding sites.
\end{abstract}

Keywords adrenal cortex hormones, glucocorticoid receptor, sepsis

\section{Introduction}

The hypothalamic-pituitary adrenal axis is a key component of the host response to sepsis, as was suggested almost a century ago following observations of apoplectic adrenal glands in fatal meningococcaemia [1,2]. In animals, removal of the adrenal cortex but sparing the medulla results in less resistance to challenge with endotoxin [3]. In recent years, advances in our understanding of the role played by glucocorticoid insufficiency in the pathogenesis of septic shock resulted in increased use of glucocorticoid replacement therapy. In a previous review article [4] we described the clinical aspects of adrenal dysfunction in sepsis, as well as the role of cortisol replacement in the management of septic shock. In the present review we detail the mechanisms of glucocorticoid insufficiency that are active during sepsis and the molecular actions of glucocorticoids.

\section{Methods}

We attempted to identify all relevant studies, regardless of language or publication status (published, unpublished, in press and in progress). We searched the following electronic databases: Medline (1966 to December 2003), Embase (1974 to December 2003) and Lilacs (www.bireme.br; accessed December 2003). Search terms used were as follows: 'septic

$\mathrm{ACTH}=$ adrenocorticotrophic hormone; $\mathrm{CBG}=$ cortisol-binding globulin; $\mathrm{CRH}=$ corticotropin-releasing hormone; GR = glucocorticoid receptor; $11 \beta$-HSD = 11 $\beta$-hydroxysteroid dehydrogenase; hsp = heat shock protein; IL = interleukin; LPS = lipopolysaccharide; MAPK = mitogen-activated protein kinase; NF- $\mathrm{KB}=$ nuclear factor- $\mathrm{KB} ; \mathrm{NOS}=$ nitric oxide synthase; $\mathrm{SRC}=$ steroid receptor coactivator; $\mathrm{TNF}=$ tumour necrosis factor. 


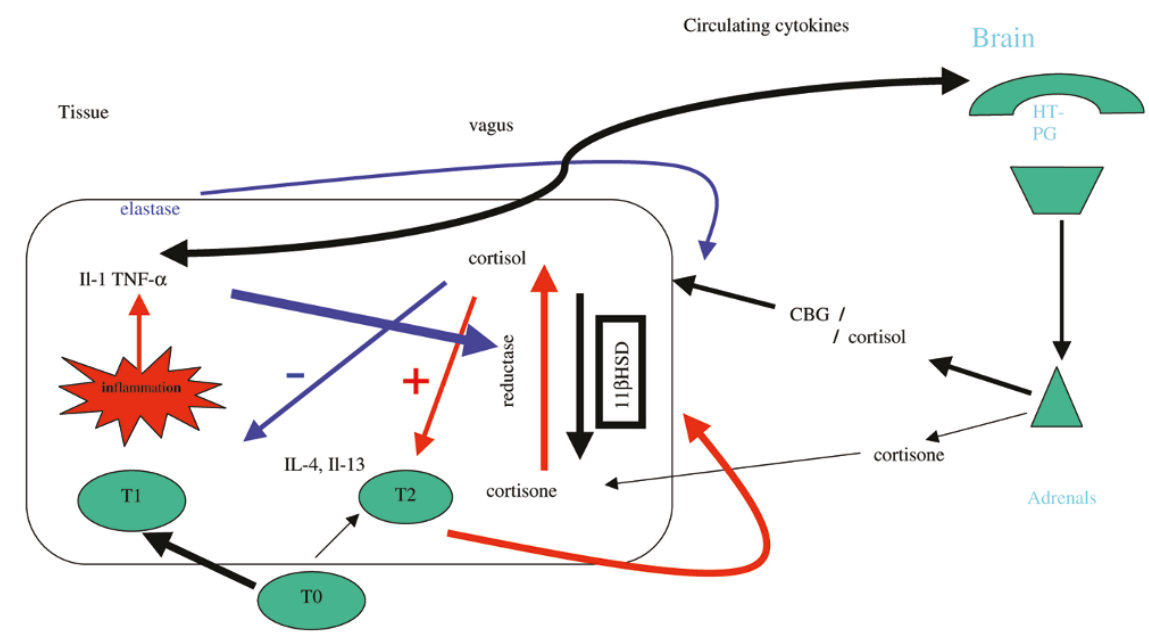

Crosstalk between the immune system and the neuroendocrine axis. $11 \beta$-HSD, $11 \beta$-hydroxysteroid dehydrogenase; CBG, cortisol-binding globulin; HT, hypothalamus; IL, interleukin; PG, pituitary gland; TNF, tumour necrosis factor.

shock', 'sepsis', 'adrenal insufficiency', 'steroids', 'corticosteroids', 'adrenal cortex hormones', 'hydrocortisone' and 'glucocorticoids'. We also checked the reference lists of all trials identified using these methods. Reports were selected on the basis of relevance to the specific topics covered.

\section{Mechanisms of glucocorticoid insufficiency}

During an acute illness such as sepsis, circulating proinflammatory cytokines, including IL-6, tumour necrosis factor (TNF)- $\alpha$ and IL-1 $\beta$, stimulate the production of corticotropinreleasing hormone $(\mathrm{CRH})$ and of adrenocotricotrophic hormone (ACTH; corticotropin; Fig. 1). Simultaneously, vagal afferent fibres detect the presence of cytokines such as IL-1 $\beta$ and TNF- $\alpha$, as well as other factors that are as yet unknown, at the site of inflammation and activate the hypothalamicpituitary axis. Numerous other factors also contribute toward upregulating ACTH synthesis, such as the noradrenergic system, vasopressin, serotonin, angiotensin and vasoactive intestinal peptide [5]. Subsequently, ACTH increases cortisol release from the adrenal glands, which then binds to a specific carrier - cortisol-binding globulin (CBG) - that is synthetized by the liver and to albumin in order to reach the target tissues. Under normal conditions, 90-95\% of plasma cortisol in humans is bound to $\mathrm{CBG}$, and it is generally accepted that the CBG-bound cortisol has restricted access to target cells $[6,7]$. At inflammatory sites, elastase produced by neutrophils liberates cortisol from CBG, allowing localized delivery of cortisol [7]. Then, cortisol can freely cross the cell's membrane, or it may interact with specific membrane binding sites. Alternatively, cortisol is inactivated by conversion to cortisone by the $11 \beta$-hydroxysteroid dehydro-
Dysfunction at any of these steps eventually results in diminished cortisol action. Thus, it can be anticipated that glucocorticoid insufficiency may be related to a decrease in glucocorticoid synthesis (i.e. adrenal insufficiency) or to reduced access of glucocorticoid to target tissues and cells.

\section{Decreased glucocorticoid synthesis}

Upon ACTH stimulation, glucocorticoids are synthesized by the adrenal cortex from cholesterol. The cholesterol required for steroidogenesis is derived from local cholesterol synthesis from acetate (about 20\%) and from exogenous sources (the remaining $80 \%$ ) [8]. Cholesterol is converted to 21 -carbon glucocorticoids and 19-carbon weak androgens in serial enzymatic steps. A small amount of corticosterone is stored as a sulphate conjugate in the adrenal cortex [9]. However, the amount of glucocorticoid found in adrenal tissue is not sufficient to account for the initial rise in cortisol that occurs following stress, and it is not sufficient to maintain normal rates of secretion for more than a few minutes in the absence of continuing biosynthesis. Thus, the rate of secretion is directly proportional to the rate of biosynthesis. In other words, any disruption in glucocorticoid synthesis will immediately result in glucocorticoid insufficiency. Adrenal insufficiency can be considered primary or secondary, although this categorization is often artificial within the context of critical illness.

\section{Secondary adrenal failure}

Sepsis may result in decreased $\mathrm{CRH}$ or ACTH synthesis by inducing irreversible anatomical damage to the hypothalamus or the pituitary gland. The anterior and posterior hypophysial arteries are derived from the internal carotid arteries. The 
Table 1

\begin{tabular}{|c|c|}
\hline Mechanisms & Drugs \\
\hline \multicolumn{2}{|l|}{ Primary adrenal insufficiency } \\
\hline Haemorrhage & Anticoagulant therapy (heparin, warfarin) \\
\hline \multirow[t]{5}{*}{ Cortisol synthesis enzyme inhibition } & Aminogluthethimide \\
\hline & Ketoconazole \\
\hline & Fluconazole \\
\hline & Etomidate \\
\hline & Dexmedetomidine \\
\hline \multirow[t]{3}{*}{ Cortisol metabolism activation } & Phenobarbital \\
\hline & Phenytoin \\
\hline & Rifampin \\
\hline \multicolumn{2}{|l|}{ Secondary adrenal insufficiency } \\
\hline \multirow[t]{6}{*}{ Suppression of CRH and ACTH synthesis } & Glucocorticoid therapy (systemic or topical) \\
\hline & Megestrol acetate \\
\hline & Medroxyprogesterone \\
\hline & Ketorolac tromethamine \\
\hline & Antidepressant drugs (e.g. imipramine) \\
\hline & Opiate drugs \\
\hline \multicolumn{2}{|l|}{ Peripheral resistance to glucocorticoids } \\
\hline Interaction with glucocorticoids receptor & Mifepristone \\
\hline \multirow[t]{2}{*}{ Inhibition of the glucocorticosteroid-induced gene transcription } & Antipsychotic drugs (e.g. chlorpromazine) \\
\hline & Antidepressant drugs (e.g. imipramine) \\
\hline
\end{tabular}

$\mathrm{ACTH}$, adrenocorticotrophic hormone; $\mathrm{CRH}$, corticotropin-releasing hormone.

arterial branches to the pars tuberalis and the primary plexus of the portal vessels in the median eminence are derived from the internal carotid and posterior communicating arteries. The venous blood passes to surrounding venous sinuses in the dura mater or in the basisphenoid bone. In many cases the arterial supply to the pars distalis is reduced or even absent, and the portal vessels may be only routes by which blood can be supplied to the anterior pituitary gland. Consequently, pituitary necrosis is a well known complication of dramatic cardiovascular collapse, as occurs in Sheehan's syndrome during the postpartum period. Within this context, glucocorticoid insufficiency is usually associated with deficiency in thyroid and growth hormones and in vasopressin. Necrosis or haemorrhage of the hypothalamus or of the pituitary gland have been reported in sepsis as a result of prolonged hypotension or severe coagulation disorders [10].

Sometimes, sepsis may exacerbate chronic known or latent secondary adrenal insufficiency, which may be due to hypothalamic or pituitary tumours, chronic inflammation, or congenital ACTH deficiency. Secondary adrenal insufficiency may also follow drug therapy (Table 1) [11]. Previous treatments with glucocorticoids induce prolonged suppression of $\mathrm{CRH}$ and $\mathrm{ACTH}$ synthesis, and result in slow onset secondary adrenal insufficiency that may outlast exposure to this treatment [12]. The duration of suppression of the hypothalamic-pituitary axis after a single dose of a glucocorticoid depends on the anti-inflammatory potency and duration of the glucocorticoid preparation, hydrocortisone being the least suppressive agent and dexamethasone the most [13]. Although systemic glucocorticoid administration is more likely to suppress the hypothalamic-pituitary axis than local treatments, adrenal insufficiency has been observed even after topical administration of glucocorticoids [14]. It is thought that after $20-30 \mathrm{mg} /$ day prednisone (or equivalent) for 5 days, the hypothalamic-pituitary axis is highly likely to be suppressed [15]. Thus, patients with sepsis who have previously been treated with glucocorticoids should be considered adrenal insufficient. It may be more cost-effective to treat all such patients with systematic replacement therapy than to target treatment at those patients who are identified by endocrine tests.

Opiate receptors are known to modulate $\mathrm{ACTH} /$ cortisol synthesis. In normal individuals administration of an opiate agonist results in a fall in plasma cortisol levels, although it induces hypotension. In contrast, administration of naloxone, an opiate antagonist, increases plasma ACTH and cortisol to levels similar to those that occur in insulin-induced hypoglycaemia [16]. Anaesthesia with high-dose diazepam and fentanyl inhibits the early increase in ACTH and cortisol 
that occurs in response to surgery, suggesting that these drugs act at the level of the hypothalamus [17,18]. Given that these drugs are commonly used for sedation in critically ill patients, one may expect that these drugs contribute, at least partly, to adrenal insufficiency in patients with sepsis.

During sepsis, suppression of $\mathrm{CRH}$ synthesis may also result from neuronal apoptosis, which may be triggered by elevation in substance P [19] or inducible nitric oxide synthase (NOS) in the hypothalamus [20]. Circulating proinflammatory mediators such as TNF- $\alpha$ may block $\mathrm{CRH}$-induced $\mathrm{ACTH}$ release [21]. Likewise, local expression of TNF- $\alpha$ and IL-1 $\beta$ may interfere with $\mathrm{CRH}$ and $\mathrm{ACTH}$ synthesis [20].

\section{Primary adrenal failure}

In sepsis, primary adrenal failure may result from bilateral necrosis and haemorrhage of the adrenals, as reported by Waterhouse [1] and Friderichsen [2]. Adrenal blood flow is about $6-7 \mathrm{ml} / \mathrm{min}$ per gram of tissue. Three small arteries derived from the inferior phrenic artery, the renal artery and the aorta form rich plexuses in the cortex and supply the gland. The plexuses are continuous with the sinuses of the medulla, which drain into the central vein of the medulla. The right adrenal vein drains into the inferior vena cava and the left into the renal vein. Hence, the rich blood supply required by the organ and the limited venous drainage (a single vein) predispose to extensive haemorrhage [22]. Experiments in animals has shown that the ACTH-stimulated (stressed) adrenal gland is more susceptible to haemorrhage [23]. Bilateral adrenal haemorrhage may be found in about $1-1.8 \%$ of autopsied patients [24] and in up to $30 \%$ of nonsurvivors from septic shock [25]. The main risk factors for hemorrhagic primary adrenal failure are increase in serum urea nitrogen of $25 \mathrm{mg} / \mathrm{dl}$ or more, positive blood cultures, shock, coagulation disorders, and anticoagulant therapy.

Sepsis may exacerbate chronic known or latent primary adrenal insufficiency, which is usually caused by autoimmune adrenalitis in developed countries and tuberculous adrenalitis in developing countries [26]. Other infectious diseases, including viral and fungal infections, may also cause chronic primary adrenal insufficiency, particularly in immunosuppressed patients. For example, morphological evaluation of adrenal glands from 128 autopsied patients with the AIDS identified compromised adrenals in $99.2 \%$ of cases, with distinct pathological features and infectious agents [27]. Cytomegalovirus is by far the commonest pathogen involved in adrenal dysfunction in AIDS patients [27,28]. Finally, genetic disorders, tumoural and nontumoural adrenal infiltration, and bilateral adrenalectomy are less common causes.

Numerous drugs that are commonly used in acutely ill patients are known to decrease cortisol synthesis (Table 1). These drugs may block enzymatic steps such as inhibition of the adrenal P450 cholesterol side-chain cleavage enzyme by adrenal $11 \beta$-hydroxylase by etomidate [30], ketoconazole [31] or high-dose fluconazole [32]. Etomidate inhibits steroidogenesis by blocking mitochondrial cytochrome P450 enzymes, and this effect may persist as long as 24 hours after a single dose of etomidate in critically ill patients [17]. Dexmedetomidine, a highly selective and potent $\alpha_{2}$ agonist, is increasingly used for postoperative sedation and analgesia [33]. It is an imidazole compound and in vitro and in vivo animal studies have shown that dexmedetomidine inhibits cortisol synthesis at a concentration that is higher than those obtained during anaesthesia in humans [34]. In addition, it has recently been shown that dexmedetomidine may be used for short-term (i.e. 24 hours) postoperative sedation in the intensive care unit without altering adrenal function [35].

During severe sepsis, circulating proinflammatory cytokines such as TNF- $\alpha$ may inhibit ACTH-induced cortisol release [36]. Neutrophil-derived corticostatins such as $\alpha$-defensins compete with ACTH on their binding sites and exert an inhibitory effect on the adrenal cells [37]. This phenomenon may explain the blunted response to exogenous ACTH that is observed in about $50 \%$ of patients with severe sepsis [38]. In less sick patients, ACTH resistance may be better unmasked by the low dose $(1 \mu \mathrm{g})$ than by the traditional $250 \mu \mathrm{g} \mathrm{ACTH}$ test [39].

Finally, cortisol metabolism may be accelerated by drug competition. Indeed, the main enzymes involved in cortisol metabolism - the microsomal $6 \beta$-hydroxylase and the cytosolic 4-ene-reductase, members of the cytochrome $3 \mathrm{~A}$ subfamily - may be inhibited by a number of drugs (Table 1), including ketoconazole and cyclosporine [40], clarithromycin [41] and antiepileptic drugs such as phenytoin [42] and phenobarbital [43].

\section{Decreased glucocorticoid delivery and action}

\section{Decreased glucocorticoid access to tissues}

CBG is a member of the serine protease inhibitor (serpin) superfamily. It has retained the stressed native structure typical of the inhibitor members of the family, and the transition from the stressed to the relaxed conformation of the protein has been adapted to allow altered hormone delivery at inflammatory sites [6]. CBG acts as a substrate for neutrophil elastase. However, CBG does not alter the activity of this enzyme but is cleaved by it at a single location close to its carboxyl-terminus; this reduces its molecular size by $5 \mathrm{kDa}$, with concomitant release of more than $80 \%$ of CBG-bound cortisol. It has been shown that granulocytes from septic patients, but not from control individuals, reduced the molecular weight of CBG by about $5 \mathrm{kDa}$ and destroyed its steroid-binding activity. These findings suggest that CBG-elastase release of cortisol allows for localized delivery of cortisol to sites of inflammation, avoiding systemic side effects [7].

CBG may also directly modulate cortisol concentration in response to a given production rate. Indeed, in dexametha- 
sone-suppressed adults, cortisol concentrations correlated with exogenous cortisol infusion rate only when adjusted for CBG levels [44]. In addition, CBG levels inversely correlated with the cortisol disappearance rate, suggesting that $\mathrm{CBG}$ actively modulates the disposition of cortisol in humans [44]. Sepsis following trauma and burns is characterized by reduced activity and amount of CBG [45-47], which may be related to circulating IL- 6 levels. In addition, reports in burned patients have shown that low-fat diet was associated with a significant increase in serum CBG concentrations, suggesting that dietary manipulations may modulate circulating CBG levels [46]. The decreased circulating CBG levels eventually result in decreased cortisol distribution and delivery to the site of inflammation and to immune cells, although the fraction of serum free cortisol is increased. In addition, at the tissue level elastase is crucial for CBG cleavage and thus for cortisol release. Therefore, drugs that inhibit elastase will prevent cortisol release from CBG and cortisol access to the tissue.

Tissue levels of cortisol are also regulated by enzymatic conversion of cortisol to its inactive form, cortisone, by the $11 \beta$-HSD type 2 . Sepsis is usually characterized by an increase in the cortisol/cortisone ratio that is proportional to the increase in acute phase protein concentration, suggesting a pivotal role for $11 \beta$-HSD isoenzyme 1 in the modulation of systemically available cortisol [48]. In addition, it has been shown that IL-1 $\beta$ and TNF- $\alpha$ upregulate $11 \beta$-HSD type 1 activity [49], and TNF- $\alpha$ decreases $11 \beta$-HSD type 2 activity [50]. Thus, in the early phase of the inflammatory process, mediators derived from the recruitment of T-helper-1 cells increase the conversion of cortisone to cortisol. Cortisone serves as an additional source for cortisol at the site of inflammation. In a second phase, cortisol enhances the recruitment of T-helper- 2 cells, and subsequently released cytokines such as IL-2, IL-4 and IL-13 stimulate $11 \beta$-HSD type 2 activity, converting cortisol to cortisone [51]. Thus, at the site of inflammation, the tight crosstalk between immune cells and cortisol allows local cortisol levels to increase in the early phase of the inflammatory process, thus counteracting the effects of proinflammatory mediators. Afterward, it allows cortisol levels to decrease, avoiding local immunosuppression. Because cytokine-regulated cortisol-cortisone shuttle plays such a pivotal role in the regulation of tissue glucocorticoid activity, the ratio of tissue cortisol/cortisone concentrations is the best marker of glucocorticoid activity.

\section{Decreased glucocorticoid receptor number/affinity}

When cortisol is delivered to target cells, it freely crosses the cell's membrane and then it interacts in the cytosol with specific receptors. Glucocorticoids mediate their effects on target immune tissues via two distinct receptor subtypes: the mineralocorticoid receptor and the glucocorticoid receptor (GR). Although the mineralocorticoid receptor has a higher affinity for circulating glucocorticoids than the GR, the GR is expressed in much higher amounts in immune tissues [52].
There are no data suggesting that sepsis or other diseases may be associated with impaired cortisol entry into the cells. Both endotoxin and lipopolysaccaride (LPS) have been shown to decrease GR affinity for ligand, mainly by inducing cytokine expression [53]. Studies have shown that cytokines may alter the GR function in various cell types, including $T$ cells [54], monocytes/macrophages [55], bronchial lung [53] and liver [55] cells. A similar reduction in GR function and affinity for ligand can be demonstrated on peripheral cells and tissues from patients with inflammatory diseases such as asthma, ulcerative colitis, AIDS, rheumatoid arthritis, acute respiratory distress syndrome and sepsis [56-64]. Investigations into GR expression yielded heterogeneous findings. Some studies found downregulation of GR [53,65-67] and others found upregulation [68-70]. These discrepancies may result from the use of different types of cells and tissues, as well as different treatments (IL- $1 \alpha$ or $\mathrm{IL}-1 \beta$, or IL inducers such as endotoxin). In addition, studies conducted in cells treated with IL-1 for 24-48 hours or in tissues from animals with chronic sepsis or patients with chronic inflammation consistently showed GR upregulation [61,70,71], whereas experiments with shorter treatments with $\mathrm{IL}-1$ inducers or conducted in the early phase of human sepsis showed GR downregulation $[53,66,67]$. Most of the studies showing GR downregulation also found decreased cytosolic GR binding, which may result from compartmentalization of the GR during the acute response to cytokines. The hypothesis of GR compartmentalization may be supported by the fact that LPS and IL-1 $\beta$ induced GR upregulation without increasing GR mRNA [69].

Potential mechanisms for cytokine-induced reduction in GR function and affinity may include inhibition of GR translocation from cytoplasm to nucleus and reduction in GR-mediated gene transcription [68]. In addition, FLICE-associated huge protein - a transducer of TNF- $\alpha$ and Fas ligand signals - may participate in TNF- $\alpha$-induced blockade of GR transactivation by binding to nuclear receptor binding domain of GRinteracting protein 1 . Thus, TNF- $\alpha$ may induce glucocorticoid resistance acting upstream and independently of nuclear factor- $\kappa \mathrm{B}(\mathrm{NF}-\kappa \mathrm{B})$ [72].

\section{Molecular action of glucocorticoids}

Glucocorticoids act by binding to a specific GR. A $94 \mathrm{kDa}$ protein, the GR is a member of the nuclear receptor family. Upon activation it dissociates from a multiprotein complex, dimerizes, enters the nucleus and binds to specific DNA regions termed glucocorticoid responsive elements (Fig. 2). The GR contains three domains. The amino-terminal domain harbours transactivation functions ( $\tau 1$ region) and regulates many biological effects. The DNA-binding domain is well conserved among the nuclear hormone receptors. The carboxyl-terminal domain, called the ligand-binding domain, also contains a transactivation region ( $\tau 2)$. At homeostasis the GR forms a multiprotein complex with numerous members of the heat shock protein (hsp) family (hsp90, 


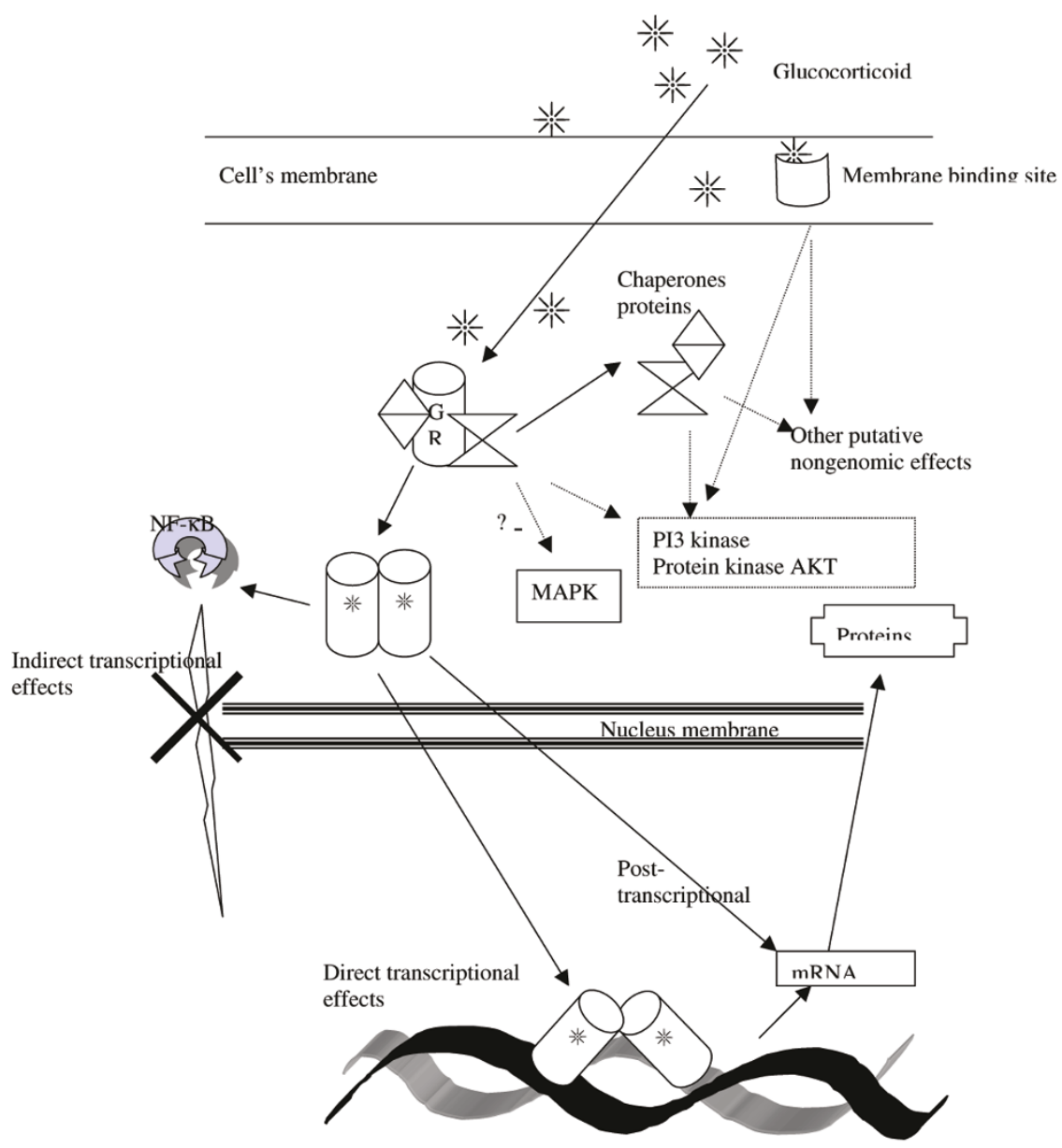

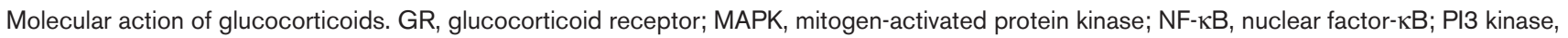
phosphatidylinositol 3-kinase.

hsp70, hsp56 and hsp40), immunophilins (FKBP51 and FKBP52), P23 and potentially other proteins that are as yet unknown [73]. The transactivation regions $\tau 1$ and $\tau 2$ probably constitute major areas for interaction with coactivator and corepressor on nuclear receptor transcriptional activities [74].

Upon activation, subsequent to ligand binding, the GR undergoes conformational changes, dissociation from other proteins (particularly shedding from hsps), dimerization, translocation to the nucleus and contact with general transcription factors, adapter proteins and various coactivators. Then, transcriptional activation or repression of specific target genes occurs and subsequently levels of regulated proteins change. In addition, post-transcriptional effects such as on mRNA may occur. GR interactions with the other proteins of the complex are still poorly understood. However, it is thought that these interactions may account for a number of rapid nongenomic biological effects of
GR, calcium signalling-related effects, and effects due to membrane events) [75]. Indeed, these effects are too rapid to allow time for transcriptional and translational events to take place, and they are insensitive to appropriate inhibitors. One must distinguish glucocorticoid-induced genomic and nongenomic effects.

\section{Genomic effects}

The GR directly activates or represses target genes by binding to hormone response elements in promoter or enhancer regions and by binding to other DNA sequence specific activators, and it can inhibit the transcriptional activities of other classes of transcription factors by transrepression. Regulation of gene trascription by nuclear receptors requires the recruitment of coregulators. Their number do not allow direct ineraction, suggesting that they act in combination or in a sequential manner [76]. Among these coregulators, the p160 steroid receptor coactivator (SRC) gene family contains three homologous members 
(SRC-1, SRC-2 and SRC-3). These coactivators are crucial in facilitating chromatin remodelling, assembly of general transcription factors, and transcription of target genes by the recruitment of histone acetyltransferases and methyltransferases to specific enhancer/promotor regions [77]. The GR-induced transrepression occurs through DNA-dependent mechanisms (i.e. displacement of an activator, overlapping binding sites, or binding to continuous negative glucocorticoid responsive element) and via DNA independent mechanisms (without direct contact between the GR and DNA). The latter includes binding of GR to a DNA-bound activator (tethering mechanism) or formation of abortive complex between $\mathrm{GR}$ and another transcription factor (squelching mechanism) [78].

Studies using DNA microarray analysis combined with quantitative TaqMan polymerase chain reaction and flow cytometry showed the complex transcriptional effects of glucocorticoids. They transactivated genes for chemokines, cytokines, complement family members and newly discovered innate immune-related genes, including scavenger and Toll-like receptors. Glucocorticoids also transrepressed adaptive immune-related genes. Finally, glucocorticoids may simultaneously transactivate and repress inflammatory T-helper subsets and apoptosis-related gene clusters [79]. Development of GR agonists that may favour transrepression over transactivation represent an exciting new field of research [80].

The NF- $\kappa B$ protein family includes $\mathrm{p} 65$ and p50, which form a complex that is maintained in its inactive form by a specific inhibitor - IאB- $\alpha$ - in the cytosol [81]. The interaction between glucocorticoids, NF- $\mathrm{KB}$ and activator protein-1 represents the main GR-induced, DNA-independent mode of transrepression and is reviewed elsewhere [82] Briefly, GR prevents activator protein-1 from interacting with its binding site within the promoters. In vitro inhibition of NF- $\mathrm{BB}$ activation has been reported in various types of cells, although an enhanced expression of the p65 component of $N F-\kappa B$ has been reported in response to glucocorticoids. In addition, the induction of $\mid \kappa B-\alpha$ by glucocorticoids further inhibits NF- $\kappa \mathrm{B}$-dependent gene transcription.

Glucocorticoids may also regulate inflammatory mediators by acting at the post-transcriptional level, on mRNA or on proteins. For example, via post-transcriptional mechanisms, dexamethasone inhibits IL-8 mRNA and protein expression in cultured airway epithelial cells [83], inhibits inducible NOS expression and activity in C6 glioma cells [84], increases macrophage migrating inhibitory factor in rat tissues [85], and increases angiotensin-converting enzyme in primary culture of adult cardiac fibroblasts [86].

\section{Nongenomic effects}

Membrane-bound receptors are thought to mediate specific nongenomic effects of glucocorticoids [87]. Indeed, membrane-binding sites for different glucocorticoids have been described in many tissues and cells, including liver plasma membranes and neuronal synaptic membranes, with evidence for both nonclassic receptors and a membrane form of classic GR [88]. Conversely, nonspecific nongenomic effects are thought to result from physicochemical membrane interactions, and to occur within seconds to minutes but only at high doses of glucocorticoid [89].

Thus far, rapid glucocorticoid action has been intensively investigated mainly in the central nervous system, and includes effects on neuronal excitability, neuroendocrine responses and behavioural tasks [90]. Some of these effects might be important in the host response to sepsis.

\section{Nonspecific nongenomic effects}

Direct membrane effects of glucocorticoids in the hypothalamic synaptosomes have been suggested as the cellular mechanism for plasma cortisol-induced negative feedback [91]. The loss of this effect may partly explain the disruption in circadian rhythm of cortisol synthesis during sepsis. Acetylcholine-induced current in pheochromocytoma cell line PC12 is inhibited by extracellular but not intracellular application of corticosterone [92]. These effects are not inhibited by the transcription inhibitors, and allow glucocorticoids to control immediate catecholamine release from sympathetic cells. This may explain the rapid restoration of the sympathetic modulation of heart rate and vasomotor tone [93], as well as the potentiation of exogenous catecholamine action that can be seen within minutes after a $50 \mathrm{mg}$ bolus of hydrocortisone in septic shock [94,95].

\section{Specific nongenomic effects}

Some of these effects may be relevant to sepsis treatment because they may account for glucocorticoid-induced rapid anti-inflammatory and cardiovascular effects.

The p38 mitogen-activated protein kinase (MAPK) participates in intracellular signalling cascades resulting in inflammatory responses. Studies in healthy volunteers challenged with LPS showed that p38 MAPK is a determinant of LPS-induced cytokine production, leucocyte responses [96], neutrophil activation and chemotaxis [97], and of LPS-induced coagulation activation, fibrinolysis inhibition and endothelial cell activation [98]. The classic GR may interfere directly with Raf-1, which is downstream of Ras in MAPK cascade, or via 14-3-3 (an adapter protein that is known to interplay with proteins such as protein kinase $C$ and Raf-1) [99]. In addition, the GR may inhibit Raf/MAPK extracellular signal-regulated kinase activation through protein-protein interactions [100]. Whether the interaction between GR and p38 MAPK accounts for nongenomic antiinflammatory effects of glucocorticoids remains to be investigated.

Membrane GRs that are present in normal and in cancerous lymphoid cells may be involved in disruption of the 
mitochondrial membrane potential and in decreased ATP availability, and subsequently may lead to apoptosis [101].

It has recently been shown that glucocorticoids, through nonnuclear activation of phosphatidylinositol 3-kinase and the proteine kinase Akt, could exert perfusion-independent protective effects in a model of ischaemic brain injury [102]. Similarly, binding of glucocorticoids to the GR-stimulated phosphatidylinositol 3-kinase and protein kinase Akt, leading to endothelial NOS activation and nitric oxide dependent vasorelaxation, is the mechanism by which glucocorticoids decreased vascular inflammation and reduced myocardial infarct size following ischaemia/reperfusion injury in mice [103].

\section{Competing interests}

None declared.

\section{References}

1. Waterhouse R: Case of suprarenal apoplexy. Lancet 1911, 1: 577.

2. Friderichsen C: Nebennierenapoplexie bei kleinen Kindern. Jb Kinderheilk 1918, 87:109.

3. Witek-Janusek L, Yelich MR: Role of the adrenal cortex and medulla in the young rats' glucoregulatory response to endotoxin. Shock 1995, 3:434-439.

4. Prigent H, Maxime V, Annane D: Clinical review: Corticotherapy in sepsis. Crit Care 2003, 8:122-129.

5. Franchimont D, Kino T, Galon J, Meduri GU, Chrousos G: Glucocorticoids and inflammation revisited: the state of the art. NIH Clinical Staff Conference. Neuroimmunomodulation 2003, 10:247-260

6. Pemberton PA, Stein PE, Pepys MB, Potter JM, Carrell RW: Hormone binding globulins undergo serpin conformational change in inflammation. Nature 1988, 336:257-258.

7. Hammond GL, Smith CL, Paterson NA, Sibbald WJ: A role for corticosteroid-binding globulin in delivery of cortisol to activated neutrophils. J Clin Endocrinol Metab 1990, 71:34-39.

8. Borkowski AJ, Levin S, Delcroix C, Mahler A, Verhas V: Blood cholesterol and hydrocortisone production in man: quantitative aspects of the utilization of circulating cholesterol by the adrenals at rest and under adrenocorticotropin stimulation. J Clin Invest 1967, 46:797-811.

9. Henry FJ, Bassett JR: Corticosterone storage within the adrenal cortex: evidence for a sulphate conjugate. J Endocrinol 1985, 104:381-386.

10. Sharshar T, Annane D, Lorin de la Grandmaison G, Dorandeau A, Hopkinson NS, Gray F: The neuropathology of septic shock: a prospective case-control study. Brain Pathology 2004, 14:2133.

11. Naing KK, Dewar JA, Leese GP: Megestrol acetate therapy and secondary adrenal suppression. Cancer 1999, 86:1044-1049.

12. Krasner AS: Glucocorticoid-induced adrenal insufficiency. JAMA 1999, 282:671-676.

13. Melby JC: Drug spotlight program: systemic corticosteroid therapy: pharmacology and endocrinologic considerations. Ann Intern Med 1974, 81:505-512.

14. Levin C, Maibach HI: Topical corticosteroid-induced adrenocortical insufficiency: clinical implications. Am J Clin Dermatol 2002, 3:141-147.

15. Axelrod L: Glucocorticoid therapy. Medicine (Balt) 1976, 55:3965.

16. Grossman A, Gaillard RC, McCartney P, Rees LH, Besser GM: Opiate modulation of the pituitary-adrenal axis: effects of stress and circadian rhythm. Clin Endocrinol (Oxf) 1982, 17: 279-286.

17. Absalom A, Pledger D, Kong A: Adrenocortical function in critically ill patients $24 \mathrm{~h}$ after a single dose of etomidate. Anaesthesia 1999, 54:861-867.

18. Hall GM, Lacoumenta S, Hart GR, Burrin JM: Site of action of fentanyl in inhibiting the pituitary-adrenal response to surgery in man. Br J Anaesth 1990, 65:251-253.
19. Larsen PJ, Jessop D, Patel H, Lightman SL, Chowdrey HS: Substance $P$ inhibits the release of anterior pituitary adrenocorticotrophin via a central mechanism involving corticotrophinreleasing factor-containing neurons in the hypothalamic paraventricular nucleus. J Neuroendocrinol 1993, 5:99-105.

20. Sharshar T, Gray F, Lorin de la Grandmaison G, Hopkinson NS, Ross E, Dorandeau A, Orlikowski D, Raphael JC, Gajdos P, Annane D: Apoptosis of neurons in cardiovascular autonomic centres triggered by inducible nitric oxide synthase after death from septic shock. Lancet 2003, 362:1799-1805.

21. Gaillard RC, Turnill D, Sappino P, Muller AF: Tumor necrosis factor alpha inhibits the hormonal response of the pituitary gland to hypothalamic releasing factors. Endocrinology 1990, 127:101-106.

22. Arnold G, Richer AG, Lepore JJ: Sal hemorrhage in pregnancy. Report of a case with review of the literature. $N$ Engl J Med 1949, 240:1040-1045.

23. Levin J, Cluff LE: Endotoxemia and adrenal hemorrhage. A mechanism for the Waterhouse-Friderichsen syndrome. J Exp Med 1965, 121:247-260.

24. Xarli VP, Steele AA, Davis PJ, Buescher ES, Rios CN, GarciaBunuel R: Adrenal hemorrhage in the adult. Medicine (Balt) 1978, 57:211-221.

25. Annane D, Bellissant E, Bollaert PE, Auriant I, Ghez D, Raphael JC: The hypothalamo-pituitary axis in septic shock. $\mathrm{Br} J$ Intens Care 1996, 6:260-268.

26. Arlt W, Allolio B: Adrenal insufficiency. Lancet 2003, 361:18811893

27. Rodrigues D, Reis M, Teixeira V, Silva-Vergara M, Filho DC, Adad $\mathrm{S}$, Lazo J: Pathologic findings in the adrenal glands of autopsied patients with acquired immunodeficiency syndrome. Pathol Res Pract 2002, 198:25-30.

28. Findling JW, Buggy BP, Gilson IH, Brummitt CF, Bernstein BM, Raff $\mathrm{H}$ : Longitudinal evaluation of adrenocortical function in patients infected with the human immunodeficiency virus. $J$ Clin Endocrinol Metab 1994, 79:1091-1096.

29. Murray M, Cantrill E, Farrell GC: Induction of cytochrome P450 2B1 in rat liver by the aromatase inhibitor aminoglutethimide. $J$ Pharmacol Exp Ther 1993, 265:477-481.

30. de Jong FH, Mallios C, Jansen C, Scheck PA, Lamberts SW: Etomidate suppresses adrenocortical function by inhibition of 11 beta-hydroxylation. J Clin Endocrinol Metab 1984, 59:11431147.

31. Britton H, Shehab Z, Lightner E, New M, Chow D: Adrenal response in children receiving high doses of ketoconazole for systemic coccidioidomycosis. J Pediatr 1988, 112:488-492.

32. Albert SG, DeLeon MJ, Silverberg AB: Possible association between high-dose fluconazole and adrenal insufficiency in critically ill patients. Crit Care Med 2001, 29:668-670.

33. Venn RM, Bradshaw CJ, Spencer R, Brealey D, Caudwell E, Naughton C, Vedio A, Singer M, Feneck R, Treacher D, Willatts SM, Grounds RM: Preliminary UK experience of dexmedetomidine, a novel agent for postoperative sedation in the intensive care unit. Anaesthesia 1999, 54:1136-1142.

34. Maze M, Virtanen R, Daunt D, Banks SJ, Stover EP, Feldman D: Effects of dexmedetomidine, a novel imidazole sedativeanesthetic agent, on adrenal steroidogenesis: in vivo and in vitro studies. Anesth Analg 1991, 73:204-208.

35. Venn RM, Bryant A, Hall GM, Grounds RM: Effects of dexmedetomidine on adrenocortical function, and the cardiovascular, endocrine and inflammatory responses in post-operative patients needing sedation in the intensive care unit. Br J Anaesth 2001, 86:650-656.

36. Jaattela M, Ilvesmaki V, Voutilainen R, Stenman UH, Saksela E: Tumor necrosis factor as a potent inhibitor of adrenocorticotropin-induced cortisol production and steroidogenic P450 enzyme gene expression in cultured human fetal adrenal cells. Endocrinology 1991, 128:623-629.

37. Tominaga T, Fukata J, Naito Y, Nakai Y, Funakoshi S, Fujii N, Imura $\mathrm{H}$ : Effects of corticostatin-I on rat adrenal cells in vitro. $J$ Endocrinol 1990, 125:287-292.

38. Annane D, Sebille V, Troche G, Raphael JC, Gajdos P, Bellissant $\mathrm{E}$ : A 3-level prognostic classification in septic shock based on cortisol levels and cortisol response to corticotropin. JAMA 2000, 283:1038-1045.

39. Marik PE, Zaloga GP: Adrenal insufficiency during septic shock. Crit Care Med 2003, 31:141-145. 
40. Abel SM, Back DJ: Cortisol metabolism in vitro: III. Inhibition of microsomal 6 beta-hydroxylase and cytosolic 4-enereductase. J Steroid Biochem Mol Biol 1993, 46:827-232.

41. Ushiama $H$, Echizen $H$, Nachi $S$, Ohnishi A: Dose-dependent inhibition of CYP3A activity by clarithromycin during Helicobacter pylori eradication therapy assessed by changes in plasma lansoprazole levels and partial cortisol clearance to 6beta-hydroxycortisol. Clin Pharmacol Ther 2002, 72:33-43.

42. Ostrowska Z, Buntner B, Rosciszewska D, Guz I: Adrenal cortex hormones in male epileptic patients before and during a 2year phenytoin treatment. J Neurol Neurosurg Psychiatry 1988, 51:374-378.

43. Negrie C, Naltchayan S, Bouhnik J, Michel R: Comparative effects of dexamethasone and phenobarbital on adrenal cortex, liver cytochrome P450 contents and serum thyroid hormones. J Steroid Biochem 1979, 10:431-435.

44. Bright GM, Darmaun D: Corticosteroid-binding globulin modulates cortisol concentration responses to a given production rate. J Clin Endocrinol Metab 1995, 80:764-769.

45. Beishuizen A, Thijs LG, Vermes I: Patterns of corticosteroidbinding globulin and the free cortisol index during septic shock and multitrauma. Intensive Care Med 2001, 27:1584-1591.

46. Garrel DR: Corticosteroid-binding globulin during inflammation and burn injury: nutritional modulation and clinical implications. Horm Res 1996, 45:245-251.

47. Pugeat $M$, Bonneton $A$, Perrot $D$, Rocle-Nicolas $B$, Lejeune $H$, Grenot C, Dechaud H, Brebant C, Motin J, Cuilleron CY: Decreased immunoreactivity and binding activity of corticosteroid-binding globulin in serum in septic shock. Clin Chem 1989, 35:1675-1679.

48. Vogeser M, Zachoval R, Felbinger TW, Jacob K: Increased ratio of serum cortisol to cortisone in acute-phase response. Horm Res 2002, 58:172-175.

49. Escher G, Galli I, Vishwanath BS, Frey BM, Frey FJ: Tumor necrosis factor alpha and interleukin 1beta enhance the cortisone/cortisol shuttle. J Exp Med 1997, 186:189-198.

50. Heiniger CD, Rochat MK, Frey FJ, Frey BM: TNF-alpha enhances intracellular glucocorticoid availability. FEBS Lett 2001, 507:351-356.

51. Rook G, Baker R, Walker B, Honour J, Jessop D, HernandezPando R, Arriaga K, Shaw R, Zumla A, Lightman S: Local regulation of glucocorticoid activity in sites of inflammation. Insights from the study of tuberculosis. Ann $N$ Y Acad Sci 2000, 917:913-922.

52. Miller AH, Spencer RL, Stein M, McEwen BS: Adrenal steroid receptor binding in spleen and thymus after stress or dexamethasone. Am J Physiol 1990, 259:E405-E412.

53. Liu LY, Sun B, Tian Y, Lu BZ, Wang J: Changes of pulmonary glucocorticoid receptor and phospholipase A2 in sheep with acute lung injury after high dose endotoxin infusion. $A m$ Rev Respir Dis 1993, 148:878-881.

54. Kam JC, Szefler SJ, Surs W, Sher ER, Leung DY: Combination IL-2 and IL-4 reduces glucocorticoid receptor-binding affinity and T cell response to glucocorticoids. J Immunol 1993, 151: 3460-3466.

55. Falus A, Biro J, Rakasz E: Cytokine networks and corticosteroid receptors. Ann N Y Acad Sci 1995, 762:71-87; discussion 7778.

56. Meduri GU, Tolley EA, Chrousos GP, Stentz F: Prolonged methylprednisolone treatment suppresses systemic inflammation in patients with unresolving acute respiratory distress syndrome: evidence for inadequate endogenous glucocorticoid secretion and inflammation-induced immune cell resistance to glucocorticoids. Am J Respir Crit Care Med 2002, 165:983-991.

57. Fan $M H$, Klein RD, Steinstraesser L, Merry AC, Nemzek JA, Remick DG, Wang SC, Su GL: An essential role for lipopolysaccharide-binding protein in pulmonary innate immune responses. Shock 2002, 18:248-254.

58. Corrigan CJ, Brown PH, Barnes NC, Szefler SJ, Tsai JJ, Frew AJ, Kay AB: Glucocorticoid resistance in chronic asthma. Glucocorticoid pharmacokinetics, glucocorticoid receptor characteristics, and inhibition of peripheral blood $\mathrm{T}$ cell proliferation by glucocorticoids in vitro. Am Rev Respir Dis 1991, 144:1016-1025.

59. Lamberts SW: The glucocorticoid insensitivity syndrome. Horm Res 1996, Suppl 1:2-4.
60. Norbiato G, Bevilacqua M, Vago T, Clerici M: Glucocorticoids and interferon-alpha in the acquired immunodeficiency syndrome. J Clin Endocrinol Metab 1996, 81:2601-2606.

61. Sher ER, Leung DY, Surs W, Kam JC, Zieg G, Kamada AK, Szefler SJ: Steroid-resistant asthma. Cellular mechanisms contributing to inadequate response to glucocorticoid therapy. J Clin Invest 1994, 93:33-39.

62. Shimada T, Hiwatashi N, Yamazaki H, Kinouchi Y, Toyota T: Glucocorticoid receptor in peripheral mononuclear leukocytes from patients with ulcerative colitis. Gastroenterology 1993, 104:A781.

63. Spahn JD, Landwehr LP, Nimmagadda S, Surs W, Leung DY, Szefler SJ: Effects of glucocorticoids on lymphocyte activation in patients with steroid-sensitive and steroid-resistant asthma. J Allergy Clin Immunol 1996, 98:1073-1079.

64. Spahn JD, Leung DY, Surs W, Harbeck RJ, Nimmagadda S, Szefler SJ: Reduced glucocorticoid binding affinity in asthma is related to ongoing allergic inflammation. Am J Respir Crit Care Med 1995, 151:1709-1714.

65. Hill MR, Stith RD, McCallum RE: Interleukin 1: a regulatory role in glucocorticoid-regulated hepatic metabolism. J Immunol 1986, 137:858-862.

66. Hill MR, Stith RD, McCallum RE: Human recombinant IL-1 alters glucocorticoid receptor function in Reuber hepatoma cells. J Immunol 1988, 141:1522-1528.

67. Molijn GJ, Koper JW, van Uffelen CJ, de Jong FH, Brinkmann AO, Bruining HA, Lamberts SW: Temperature-induced downregulation of the glucocorticoid receptor in peripheral blood mononuclear leucocyte in patients with sepsis or septic shock. Clin Endocrinol (Oxf) 1995, 43:197-203.

68. Pariante CM, Pearce BD, Pisell TL, Sanchez Cl, Po C, Su C, Miller $\mathrm{AH}$ : The proinflammatory cytokine, interleukin-1alpha, reduces glucocorticoid receptor translocation and function. Endocrinology 1999, 140:4359-4366.

69. Verheggen MM, van Hal PT, Adriaansen-Soeting PW, Goense BJ, Hoogsteden HC, Brinkmann AO, Versnel MA: Modulation of glucocorticoid receptor expression in human bronchial epithelial cell lines by IL-1 beta, TNF-alpha and1 LPS. Eur Respir J 1996, 9:2036-2043.

70. Sun X, Mammen JM, Tian X: Sepsis induces the transcription of the glucocorticoid receptor in skeleta muscle cells. Clin $\mathrm{Sci}$ (Lond) 2003, 105:383-391.

71. Costas M, Trapp T, Pereda MP, Sauer J, Rupprecht R, Nahmod WE, Reul JM, Holsboer F, Arzt E: Molecular and functional evidence for in vitro cytokine enhancement of human and murine target cell sensitivity to glucocorticoids. TNF-alpha priming increases glucocorticoid inhibition of TNF-alpha-induced cytotoxicity/apoptosis. J Clin Invest 1996, 98:1409-1416.

72. Kino T, Chrousos GP: Tumor necrosis factor alpha receptorand Fas-associated FLASH inhibit transcriptional activity of the glucocorticoid receptor by binding to and interfering with its interaction with $\mathrm{p} 160$ type nuclear receptor coactivators. $J$ Biol Chem 2003, 278:3023-3029.

73. Freeman BC, Yamamoto KR: Continuous recycling: a mechanism for modulatory signal transduction. Trends Biomed Sci 2001, 26:286-290.

74. McKenna NJ, O'Malley BW: Minireview: nuclear receptor coactivators: an update. Endocrinology 2002, 143:2461-2465.

75. Sutter-Dub MT: Rapid non-genomic and genomic responses to progestogens, estrogens, and glucocorticoids in the endocrine pancreatic B cell, the adipocyte and other cell types. Steroids 2002, 67:77-93.

76. Rosenfeld MG, Glass CK: Coregulator codes of transcriptional regulation by nuclear receptors. J Biol Chem 2001, 276: 36865-36868.

77. Xu J, Li Q: Review of the in vivo functions of the p160 steroid receptor coactivator family. Mol Endocrinol 2003, 17:1681-1692.

78. Miner $\mathrm{JH}$, Wold $\mathrm{BJ}$ : c-myc inhibition of MyoD and myogenininitiated myogenic differentiation. Mol Cell Biol 1991, 11: 2842-2851.

79. Galon J, Franchimont D, Hiroi N, Frey G, Boettner A, EhrhartBornstein M, O'Shea JJ, Chrousos GP, Bornstein SR: Gene profiling reveals unknown enhancing and suppressive actions of glucocorticoids on immune cells. FASEB J 2002, 16:61-71.

80. Schacke $H$, Schottelius A, Docke WD, Strehlke $P$, Jaroch $S$, Schmees N, Rehwinkel H, Hennekes H, Asadullah K: Dissociation of transactivation from transrepression by a 
selective glucocorticoid receptor agonist leads to separation of therapeutic effects from side effects. Proc Natl Acad Sci USA 2004, 101:227-232.

81. Li Q, Verma IM: NF-kappaB regulation in the immune system. Nat Rev Immunol 2002, 2:725-734.

82. Annane D, Cavaillon JM: Corticosteroids in sepsis: from bench to bedside? Shock 2003, 20:197-207.

83. Chang MM, Juarez M, Hyde DM, Wu R: Mechanism of dexamethasone-mediated interleukin-8 gene suppression in cultured airway epithelial cells. Am J Physiol Lung Cell Mol Physiol 2001, 280:L107-L115.

84. Shinoda J, McLaughlin KE, Bell HS, Swaroop GR, Yamaguchi S, Holmes MC, Whittle IR: Molecular mechanisms underlying dexamethasone inhibition of iNOS expression and activity in C6 glioma cells. Glia 2003, 42:68-76.

85. Fingerle-Rowson G, Koch P, Bikoff R, Lin X, Metz CN, Dhabhar FS, Meinhardt A, Bucala R: Regulation of macrophage migration inhibitory factor expression by glucocorticoids in vivo. Am J Pathol 2003, 162:47-56.

86. Barreto-Chaves ML, Aneas I, Krieger JE: Glucocorticoid regulation of angiotensin-converting enzyme in primary culture of adult cardiac fibroblasts. Am J Physiol Regul Integr Comp Physiol 2001, 280:R25-R32.

87. Wehling $M$ : Specific, nongenomic actions of steroid hormones. Annu Rev Physiol 1997, 59:365-393.

88. Orchinik M, Matthews L, Gasser PJ: Distinct specificity for corticosteroid binding sites in amphibian cytosol, neuronal membranes, and plasma. Gen Comp Endocrinol 2000, 118: 284-301.

89. Buttgereit $F$, Wehling M, Burmester GR: A new hypothesis of modular glucocorticoid actions: steroid treatment of rheumatic diseases revisited. Arthritis Rheum 1998, 41:761767.

90. Losel RM, Falkenstein E, Feuring M, Schultz A, Tillmann HC, Rossol-Haseroth K, Wehling $\mathrm{M}$ : Nongenomic steroid action: controversies, questions, and answers. Physiol Rev 2003, 83: 965-1016.

91. Edwardson JA, Bennett GW: Modulation of corticotrophinreleasing factor release from hypothalamic synaptosomes. Nature 1974, 251:425-427.

92. Shi LJ, He HY, Liu LA, Wang CA: Rapid nongenomic effect of corticosterone on neuronal nicotinic acetylcholine receptor in PC12 cells. Arch Biochem Biophys 2001, 394:145-150.

93. Orlikowski D, Sharshar T, Castel M, Annane D: Acute effects of a single intravenous bolus of $50-\mathrm{mg}$ hydrocortisone on cardiovascular autonomic modulation in septic shock. Crit Care Med 2003, 31(suppl):A124.

94. Annane D, Bellissant E, Sebille V, Lesieur O, Mathieu B, Raphael $J C$, Gajdos P: Impaired pressor sensitivity to noradrenaline in septic shock patients with and without impaired adrenal function reserve. Br J Clin Pharmacol 1998, 46:589-597.

95. Bellissant $E$, Annane $D$ : Effect of hydrocortisone on phenylephrine: mean arterial pressure dose-response relationship in septic shock. Clin Pharmacol Ther 2000, 68:293-303.

96. Branger J, van den Blink B, Weijer S, Madwed J, Bos CL, Gupta A, Yong CL, Polmar SH, Olszyna DP, Hack CE, van Deventer SJ, Peppelenbosch MP, van der Poll T: Anti-inflammatory effects of a p38 mitogen-activated protein kinase inhibitor during human endotoxemia. J Immuno/ 2002, 168:4070-4077.

97. Van Den Blink B, Branger J, Weijer S, Gupta A, Van Deventer SJ, Peppelenbosch MP, Van Der Poll T: P38 mitogen activated protein kinase is involved in the downregulation of granulocyte CXC chemokine receptors 1 and 2 during human endotoxemia. J Clin Immunol 2004, 24:37-41.

98. Branger J, van den Blink B, Weijer S, Gupta A, van Deventer SJ, Hack CE, Peppelenbosch MP, van der Poll T: Inhibition of coagulation, fibrinolysis, and endothelial cell activation by a p38 mitogen-activated protein kinase inhibitor during human endotoxemia. Blood 2003, 101:4446-4448.

99. Wikstrom AC: Glucocorticoid action and novel mechanisms of steroid resistance: role of glucocorticoid receptor-interacting proteins for glucocorticoid responsiveness. J Endocrino/ 2003, 178:331-337.

100. Ayroldi E, Zollo O, Macchiarulo A, Di Marco B, Marchetti C, Riccardi C: Glucocorticoid-induced leucine zipper inhibits the Raf-extracellular signal-regulated kinase pathway by binding
101. Buttgereit F, Burmester GR, Brand MD: Bioenergetics of immune functions: fundamental and therapeutic aspects. Immunol Today 2000, 21:192-199.

102. Limbourg FP, Huang Z, Plumier JC, Simoncini T, Fujioka M, Tuckermann J, Schutz G, Moskowitz MA, Liao JK: Rapid nontranscriptional activation of endothelial nitric oxide synthase mediates increased cerebral blood flow and stroke protection by corticosteroids. J Clin Invest 2002, 110:17291738.

103. Hafezi-Moghadam A, Simoncini T, Yang E, Limbourg FP, Plumier JC, Rebsamen MC, Hsieh CM, Chui DS, Thomas KL, Prorock AJ, Laubach VE, Moskowitz MA, French BA, Ley K, Liao JK: Acute cardiovascular protective effects of corticosteroids are mediated by non-transcriptional activation of endothelial nitric oxide synthase. Nat Med 2002, 8:473-479. 